\title{
27 Kasım 2014 IDEA Dünya Yaratıcı Drama Günü Ulusal Bildirgesi
}

"Drama; hayata, hayatın içinde, uzaktan bakabilmektir."

Hayatı duyularımızla algılar, bilişimizle anlar, yorumlar ve ona ilişkin yeni seçenekler ile çözümler üretiriz. İnsan olmanın en önemli özelliği yorumlayabilme, düşünebilme ve sorgulama becerilerimizin olmasıdır. Günümüzde eğitim, beşikten üniversite sıralarına kadar insanın temel özelliklerini geliştirmek yerine onlara ket vurmaktadır. "Karayeller başımıza indirmeden çatımızı" durup düşünmek ve nasıl oluyor da bu durumda olduğumuzu sorgulamak gerekiyor. İnsanın insanla, insanca yaşaması için; farklılıkları birlikte yaşatacak ve hoşgörü sağlayacak insani özelliklerin yaşatılması için Rıfat Ilgaz ustanın dediği gibi “ses, olmanın, ışık olmanın yumruk olmanın” zamanı gelmedi mi? "Karayeller başlarımıza indirmeden çatılarımızı, sel suları bastığımız toprakları alıp götürmeden büyük denizlere, çabuk olmalıyız!” Düşünen ve sorgulayan, üreten ve paylaşan yurttaşlar yetiştirmek aydınların görevi ise öğrenenlerin bu görevi yaşarmışçasına duymalarını, görmelerini, hissetmelerini ve düşünmelerini sağlayabilecek en iyi yöntem yaratıcı dramadır.

Yaratıcı drama; geçtiği yolları, insanları, düşünceleri ve kalpleri birbirine bağlayan bir nehir gibidir. Kesişen ve kesişecek olan tüm yollarda evrensel değerleri yaşatabilmek, insana insanca bir yaşam için mücadele etmek, demokrasi kültürünü yerleştirmek ve bunu bilişsel, duyuşsal ve davranışsal hale getirebilmek için yaratııılı̆̆ inancımızı yeniden kurmak gerek. Aydın olmanın sorumluluğunu yeniden üstlenmek, ülkemiz ve tüm insanlar için iyi şeyler yapabileceğimizin farkında olmak gerek. İnsan, eylemde bulunmadan insani özellikleri kazanamaz, eylemin temeli, diğer insanlarla birlikte yaşayabilmektir. İnsan doğuştan itibaren oynamaya başlar, eyler kendini. Eylemin en kendiliğinden hali yaratıcı dramada var olur, birey "ben"ini grupla "biz”e taşıyarak üretir ve ürettiklerinin doğurgularına dışardan bakarak onu içselleştirir. Yaratıcı dramanın gözleriyle bakmanın, büyük yolculuklara çıkmanın bugün artık daha fazla zamanıdır. Önce kendimizi sorgulamanın, rollerimizin farkına varmanın, yaşamdaki gerçekleri algılayıp içi boşaltılmadan "farkındalık" çerçevesinde paylaşmanın...

Yaratıcı drama eğitmenleri olarak toplumsal sorumluluklarımızı yerine getirmek için; yaratıcılığın ve sanatın sınırlarını zorlayabilir, bugün ve yarın için iyi insana ve yarınlara olan inancımızı yaratıcı dramayla haykırabiliriz. İnsanlar, toplumlar ve dünya için sorumluluk almak ve bu sorumluluklarımızın bilincinde olmak umuduyla, yabancılaşmadan, yabancılaştırmadan...

27 Kasım Dünya Yaratıcı Drama Günümüz kutlu olsun.

Yrd. Doç. Dr. Fatma Önalan Akfırat

Çağdaş Drama Derneği Yaratıcı Drama Eğitmeni Lefke Avrupa Üniversitesi Öğretim Üyesi 


\section{Kasım 2014 (IDEA) Dünya Yaratıcı Drama Günü Uluslararası Bildirgesi}

Her 27 Kasım'da Dünya Yaratıcı Drama Günü için uluslararası bir bildirge kaleme alan IDEA, 2014'ün “Çocuk Hakları Sözleşmesinin Kabulünün 25. Yıldönümü” olması nedeniyle, bu yı1 çocukların haklarına vurgu yapan; dramanın, tiyatronun ve eğitimin savunucularının aynı zamanda “Çocuk Hakları”nın da savunucuları olduğuklarına ilişkin çok dilli kısa bir video hazırlamıştır.

\section{Değerli IDEA Üyeleri ve Dramaya, Eğitime ve Sanatlar Eğitimine Destek Veren Herkese Merhaba,}

Bildiğiniz gibi 27 Kasım IDEA tarafından Uluslararası Drama/Tiyatro ve Eğitim Günü olarak belirlenmiştir. Her yıl bu günde, drama ve sanat eğitimcilerine, bugünü kutlamaları, alanı savunmaları ve eyleme geçmeleri için bir çağrı yapıyoruz.

Kasım ayında, Almanya’nın Rostock kentinde gerçekleştirilmiş olan IDEA Yönetim Kurulu Toplantısın'ın Genel Kurul Başkanı olan Sanja Krsmanovic Tasic, bizlere 2014'ün Çocuk Hakları Sözleşmesi'nin kabulünün 25. yıldönümü olduğunu anımsattı. Araştırmadan sorumlu yönetim kurulu üyesi Peter Duffy ise bu konuya vurgu yapan çokdilli kısa bir videonun hazırlanması ve yayılması amaciyla hemen harekete geçti.

Ben de 27 Kasım'1 kutlayan, drama, tiyatro ve eğitimi savunan, bu alanlar için eylemde olan tüm IDEA üyelerine hazırlanan videonun yaygınlaştırılması konusunda 1srarda bulunuyorum.

https://www.youtube.com/watch?v=FkC-oM1J2N0\&list=UU_cubpo5U17PST1DQUkMaKQ\&index=1

RobinPascoe

IDEA Başkanı

Çevirenler: Zeki Özen, İhsan Metinnam 


\section{7th November 2014 IDEA World Creative Drama Day International Declaration}

\section{Dear IDEA members and all who support drama education and arts education,}

IDEA has declared November 27 each year as International Drama/Theatre Education Day. Each year, we call on all drama and arts educators to celebrate, to advocate and to act. At the meeting of the Elected Officers of IDEA in Rostock, Germany, in November, Sanja Krsmanovic Tasic, President of the General Council, reminded us that 2014 was the 25th Anniversary of the Declaration of the Rights of Children. Peter Duffy, Director of Research, galvanised action to create a short multilingual video to spread the word.

https://www.youtube.com/watch?v=FkC-oM1J2N0\&list=UU_cubpo5U17PST1DQUkMaKQ\&index=1

I urge all members of IDEA to spread the word and to make links to this short video as they celebrate, advocate and act for drama, theatre and education.

RobinPascoe

President of IDEA 


\section{Yaratıcı Drama Dergisine İlişkin Açıklamalar ve Yazım Kuralları}

\section{Yaratıcı Drama Dergisi’ne yayımlanmak üzere gönderilen yazılar:}

1. Alana uygunluk açısından öncelikle editör tarafından incelenerek yayın kuruluna iletilir. Yayımlanmasına karar verilen yazılar, bilimsel açıdan değerlendirilmek üzere en az iki hakem tarafindan incelenir.

2. Hakem raporlarından birinin olumlu, diğerinin olumsuz olması durumunda, makale değerlendirilmek üzere üçüncü hakeme yönlendirilir. Hakem raporlarının olumlu olması durumunda yazı, yayım programına alınır.

3. Hakem raporlarına göre üzerinde değişiklik yapılması gereken yazılardaki tüm değişiklikleri yazarlar kendileri yaparlar. Son şekli verilen yazılar üzerinde yazarlarca bir değişiklik yapılmaz.

4. Hakem raporları gizlilik içerir. Yazarlar, hakem ve Yayın Kurulu'nun eleştiri, öneri ve düzeltmelerini dikkate almak zorundadırlar. Yazarlarla hakemler arasındaki iletişimi yalnızca Yayın Kurulu sağlar.

5. Yayım sırasında, ilk olarak yazının Yaratıcı Drama Dergisi'ne gönderiliş tarihi, sonra da hakemlerden alınan puanlar dikkate alınmaktadır.

6. Yaratıcı Drama Dergisi'nde yayımlanan yazıların sorumluluğu yazar/lar/a aittir. Yayımlanan yazılar konusunda Çağdaş Drama Derneği ve Yaratıcı Drama Dergisi sorumluluk kabul etmez.

7. Yayın Kurulu, gönderilen yazıları yayımlayıp yayımlamamakta serbesttir. Gönderilen yazılar yayımlansın veya yayımlanmasın yazara iade edilmez.

8. Yayımlanmış yazıların yayın hakları Yaratıcı Drama Dergisi’ne aittir.

9. Yaratıcı Drama Dergisi'nin ve yazar/ların adları kaynak gösterilerek alıntı yapılabilir.

10. Yazılar, yazar soyadına göre alfabetik sırada yayımlanır. İki ya da daha fazla yazarlı makalelerde yazılar, ilk yazarın soyadı esas alınarak sıralanıp yayımlanır.

11. Bir sayıda, aynı yazarın tek isim olduğu tek makale yayımlanabilir.

12. Dergiye gönderilecek yazllar;

a. Kăğt boyutları: A4 boyutunda kağıda, üst, alt, sağ ve soldan $2,5 \mathrm{~cm}$ boşluk bırakılarak (16x24,7 cm'lik alana), 1,5 satır aralıklı, 11 punto ve Times New Roman yazı karakteri kullanılarak yazılmalıdır.

b. Tablo, resim, şekil, grafik vb.: Derginin sayfa boyutlarının dışına taşmaması amacıyla 10x17 cm'lik alanı aşmamalıdır. Tablo, resim, şekil, grafik ve benzerlerinde daha küçük punto ve bir satır aralığı kullanılabilir. Tablo, şekil ve ekler, metin içerisinde, başlıklarıyla yer almalıdır. Tablo ve şekillerin öncesine ve sonrasına 12 nk boşluk verilir, tablo başlıkları ve metin 10 punto, tablo ve numarası koyu yazılmalıdır.

c. Makale Başlı̆ğ; 14 punto, bağlaçlar hariç her sözcüğün baş harfi büyük olarak yazılmalıdır. Başlık 17 sözcüğü geçmemelidir. Proje kapsamında hazırlanan, sözlü bildiri, doktora ya da yüksek lisans tezinden üretilmiş veya destek almış çalışmalar başlığa * şeklinde dipnot ile verilir. Başlıktan sonra bir boşluk ile dipnot verilmelidir. 
d. Yazar Ad/lar/ı; 12 punto, ortalı, yazar adı soyadı sadece baş harfleri büyük olarak dipnotta rakamla $1-2$ şeklinde verilmelidir.

e. Özet Başlı̆̆ı; 10 punto ve koyu yazılmalıdır.

f. Türkçe/Ingilizce Özet Metni; 10 punto, iki tarafa yaslı şekilde, 150-250 sözcük arası yazılmalıdır. Paragraf var ise paragraflar aras $6 \mathrm{nk}$ boşluk verilmelidir.

g. Anahtar Sözcükler Başlı̆̆ı; 10 punto, koyu yazılmalıdır.

h. Anahtar Sözcükler; 10 punto büyüklüğ̈̈nde, en fazla 5 anahtar sözcük yazılmalıdır.

i. Ana Başlıklar; (Giriş, Yöntem, Tartışma ve benzeri temel başlıklar)10 punto, koyu ve ortalı, altından ve üstünden $6 \mathrm{nk}$ boşluk ile yazılmalıdır.

j. Alt Başlıklar; paragraf baş1 1,25 cm içerden, 11 punto, koyu, italik, iki yana yasılı yazılmalıdır.

k. Paragraflar; paragraf başları 1,25 cm içeriden, 11 punto, iki yana yaslı, paragraflar arası 6 nk boşluk bırakılarak yazılmalıdır.

13. Gönderilen yazılar; özetler ve kaynakça dahil 20 sayfayı geçmemelidir.

14. Gönderilen yazılar aşağıdaki bölümleri içermelidir:

a. Başlık sayfası: Yazar/lar/ın tüm ve açık adları, çalıştıkları kurumlar, makale üst başlığının Türkçe ve İngilizce isimleri ile Türkçe ve İngilizce özetleri içermelidir.

b. Ana Metin: Ampirik çalışmalar; giriş, yöntem, bulgular, tartışma ve sonuç bölümlerini içermelidir.

c. Yöntem: $B u$ kısım; örneklem, veri toplama aracı ve işlem, verilerin analizi alt k1sımlarını içermek zorundadır. Derleme türü çalışmalar problemi ortaya koymalı, ilgili alanyazını etkili bir biçimde analiz etmeli, alanyazındaki eksiklikler, boşluklar ve çelişkilerin üzerinde durmalı ve çözümler için öneriler içermelidir. Diğer çalışmaların başlıklandırılmasında farklılıklar olabilir, ancak yazıların okuyucuyu sıkmayacak akıcılık ve bilimsellikte olması gerekmektedir.

d. Kaynakça: Hem metin içinde hem de kaynakçada Amerikan Psikologlar Birliği (APA) tarafından yayınlanan Puplication Manual of American Psychological Association (5. Bask1 2001) adlı kitapta belirtilen yazım kurallarına uyulmalıdır.

15. Yayın Kurulu ile ilgili yazışmalar için e-posta adresi mutlaka yazılmalıdır.

16. Türkçe makalelerde metin içinde referans verirken mümkün olduğu kadar ana kaynağa ulaşılmalıdır.

17. Yazılar, Yaratıcı Drama Dergisi’nin e-posta adresine (cdddergi@gmail.com) gönderilmelidir.

18. Yayımlanan yazıların içeriğinde olabilecek çarpıtmalardan, alıntı yapan yazar ya da yazarlar sorumludur.

19. Yaratıcı Drama Eğitmenlik/Liderlik kurslarında bitirme projesi olarak yapılan çalışmalar danışman adı ikinci isim olmak üzere, danışman adıyla birlikte yayımlanır.

20. Başka bir yerde yayımlanan yazılar (yayımlanmış seminer ve kongre bildirileri, vb.), Yayın Kurulu'nun onayıla Yaratıcı Drama Dergisi'nde yayımlanabilir. 


\section{Yaratıcı Drama Dergisi Kaynakça Yazım Örnekleri}

Dergimizde Amerikan Psikologlar Derneği (Publication of Manual of American Psychological Association-APA) tarafından yayınlanan yazım ilkeleri benimsenmiştir.

\section{Kitap}

Adıgüzel, Ö. (2013). Eğitimde yaratıcı drama (4.bs.). Ankara: PegemA Yayınları.

Gönderme: (Adigüzel, 2013, s.234)

\section{İki Yazarlı Kitap}

Kitson, N. ve Spiby, I. (1997). Drama 7-11: Developing primary teaching skills (3rd ed.). New York: Routledge Publication.

\section{Kitap İçinde Bölüm}

Güven, İ. (2008). Okul öncesi drama etkinliklerinde ilkeler. A. Öztürk (Yay. Haz.). Çocukta Yaratıcılık ve Drama içinde (ss. 199-212). Eskişehir: Anadolu Üniversitesi Yayınları.

Gönderme: (Güven, 2008, s.207)

\section{Çeviri Kitap}

Lewis, B. (2000). Modern Türkiye’nin doğuşu (M. Kıratlı, Çev.). Ankara: Türk Tarih Kurumu.

Gönderme: (Lewis, 2000, s. 12)

\section{Editörlü Kitap}

Kilpatrick, J. (2004). (Ed.). A Research companion to principles and xtandards for school mathematics, Reston, VA: NCTM, Inc. Educational Research Information Center (ERIC)

\section{Tek Yazarlı Makale}

San, İ. (1990). Eğitimde yaratıcı drama. Ankara Üniversitesi Ĕ̆itim Bilimleri Fakültesi Dergisi, 23(2), 573-582.

Gönderme: (San, 1990, s. 574)

\section{İki yazarlı makale}

Özdemir, P. ve Akkuş-Çıkla, O. (2005). Use of creative drama in science and mathematics by preservice elementary teachers. Hacettepe Üniversitesi Eğitim Fakültesi Dergisi, 27, 157-166.

\section{Elektronik Makale}

Karakelle, S. (2012). Üstbilişsel farkındalık, zeka, problem çözme algısı ve düşünme ihtiyacı arasındaki bağlantılar. Eğitim ve Bilim, 37(164), 237-250. 3 Aralık 2014 tarihinde http://egitimvebilim.ted.org. tr/index.php/EB/article/view/779/376 adresinden erişildi.

Gönderme: (Karakelle, 2012, s. 240)

\section{Tez}

Aykaç, M. (2011). Türkçe öğretiminde çocuk edebiyatı metinleriyle kurgulanan yaratıcı drama etkinliklerinin anlatma becerilerine etkisi. Yayınlanmamış doktora tezi, Ankara Üniversitesi Eğitim Bilimleri Enstitüsü Hacettepe, Ankara.

Gönderme: (Aykaç, 2011, s.67) 


\section{Bildiri}

Akfırat Önalan, F. ve Tunç, A. (2003). Grup rehberlik etkinliklerinde yaratıcı dramanın yeri: Yaparak yaşayarak öğrenme. VII. Ulusal Psikolojik Danışma ve Rehberlik Kongresi 09-11 Temmuz 2003 içinde (s. 91-93). İnönü Üniversitesi, Malatya: PegemA Yayıncılık, 139-140.

Gönderme: (Akfirat Önalan ve Tunç, 2003, s. 92)

\section{Web Sayfaları}

UNESCO. (2013). World Heritage list. UNESCO web sitesinden 21 Aralık 2013 tarihinde erişildi: http://whc.unesco.org/en/list

Gönderme: (UNESCO, 2013)

\section{Şekiller}

Her şeklin numarayı içeren bir başlı̆̆ 1 olmalı ve bu başlık şeklin altına yazılmalıdır.

\section{Tablolar}

Tablo numarası ve adı tablonun üstünde yer almalıdır. Tablo adı, tablo numarasının altından başlayarak, sola dayalı bir şekilde, baş harfleri büyük ve italik olarak yazılmalıdır. Tablo sadece yatay çizgiler kullanılarak oluşturulmalıdır. Aşağıda bir tablo örneği verilmiştir.

Tablo 1. Yaratıcı Drama Temelli Hazırlanan Fen ve Matematik Ders Planlarının Dağılımı

\begin{tabular}{|c|c|c|c|c|c|}
\hline & 1. sinif & 2. $\sin 1 f$ & 3. sinif & 4. $\sin 1 f$ & 5. $\sin 1 f$ \\
\hline & Fen ders & & & & \\
\hline Yaşayan canlılar & - & - & - & 5 & 1 \\
\hline \multirow[t]{2}{*}{ Elektrik } & - & - & 1 & 3 & - \\
\hline & Matema & & & & \\
\hline Sayılar & - & - & 1 & - & 1 \\
\hline Geometri & 1 & - & 3 & 1 & 1 \\
\hline Ölçme & - & 2 & 1 & - & - \\
\hline Veri analizi & - & - & 1 & - & - \\
\hline
\end{tabular}




\section{Submission Guidelines for Creative Drama Journal}

\section{Articles sent to Creative Drama Journal for Publication:}

1. Firstly, articles are delivered to editorial board by examining by the editor in terms of appropriateness to the field. The articles, which are decided to be published, are examined by at least two referees to be evaluated from a scientific point.

2. In the event that one of the referee reports is positive and the other one is negative, article is directed to the third referee to be evaluated. In case of positive referee reports, article is included in the publication program.

3. Authors make all changes in the articles on which changes are required according to referee reports on their own. No change is made on the final versions of the articles by the authors.

4. Referee reports include privacy. Authors have to take the critics, suggestions and corrections of the referee and Editorial Board into consideration. Communication between authors and referees is only ensured by the Editorial Board.

5. During publication, firstly the sending date of the article to Creative Drama Journal is considered and then the scores obtained from the referees are considered.

6. Responsibility of the articles published in Creative Drama Journal pertains to the author/s/ of the articles. Contemporary Drama Association and Creative Drama Journal do not accept responsibility related to the published articles.

7. The Editorial Board is free to publish and not to publish the submitted articles. Submitted articles are not returned to the author whether they are published or not.

8. The rights of publication of the published articles pertain to Creative Drama Journal.

9. Quotation can be made by giving reference of Creative Drama Journal and the name/s of the author/s.

10. Articles are published in alphabetical order by authors' surnames. In articles with two or more authors, articles are sorted and published based on the first author's surname.

11. In an issue, one article can be published in which the same author is the only name.

12. Articles to be sent to the journal;

a. Paper sizes: It should be written on A4 sized paper with 1.5 line spacing and without end of line hyphenation by leaving $2,5 \mathrm{~cm}$ space from top, bottom and left (on an area of $16 \times 24,7 \mathrm{~cm}$ ) and by using 11 point size and Times New Roman typeface.

b. Tables, pictures, figures, graphics, etc... They should not exceed the area of 10x17 $\mathrm{cm}$ in order not to extend beyond the journal page sizes. Smaller font size and one line space can be used on tables, pictures, figures, graphics and so on. Tables, figures and appendices should be included in the text with their titles. $12 \mathrm{pt}$ space is left before and after tables and figures, table titles and text should be 10 point size, table and its number should be written in bold.

c. Title of the Article; It should be written as 14 point size, and the first letter of every word should be written as capital letter except for the conjunctions. Title should not exceed 17 words. Studies, which are produced from verbal notification and doctoral 
or postgraduate thesis or which received support, are indicated by footnote in the title as *. Footnote should be given by a space after title.

d. Name/s of the Author/s; They should be given in footnote in figures as 1-2 along with the title, institution he/she works and e-mail address as 12 point size, centered, and only the first letters of author name and surname should be capital letter.

e. Title of Abstract; It should be written as 10 point size and in bold.

f. Turkish / English Text Abstract; It should be written as 10 point size, italic, justified alignment and between 90-120 words. If there is a paragraph, 6 pt space should be given between paragraphs.

g. Title of the Keywords; It should be written as 10 point size and in bold.

h. Keywords; Maximum 5 keywords should be written as 10 point size.

i. Main Titles; (Introduction, Method, Discussion and similar basic titles) It should be written as 11 point size, bold and centered, in the way that only the first letters are capital letter, and with $6 \mathrm{pt}$ space from top and bottom.

j. Subtitles; paragraph indentation should be written as $1.25 \mathrm{~cm}$ inside, 11 point size, bold, italic and justified alignment.

k. Paragraphs; Paragraph indentations should be written as $1.25 \mathrm{~cm}$ inside, 11 point size, justified alignment by leaving 6pt space between paragraphs.

13. Submitted articles should not exceed 20 pages, including abstracts and references.

14. Submitted articles should include the following sections:

a. Title page: It should include the full name/s and explicit name/s of the author/s, the institutions they work, Turkish and English names of top article title and its Turkish and English abstracts.

b. Main Text: Empirical studies should include the sections of introduction, method, findings, discussion and the results.

c. Method: This section must include the sub-sections of sampling, data collection and processing and analysis of data. Review article-type studies should reveal the problem, should analyze the relevant literature effectively, should put emphasis on shortcomings, gaps and contradictions in the literature and should include suggestions for solutions. There may be differences in giving title of other studies, however, articles should be fluent and scientific that will not make the readers bored.

d. References: Spelling rules specified in the book called Publication Manual of American Psychological Association ( $5^{\text {th }}$ edition 2001) published by American Psychological Association (APA) should be obeyed both in the text and references.

15. E-mail address must be written for correspondences related to the Editorial Board.

16. While giving reference in the texts in Turkish articles, main source should be attained as far as possible.

17. Articles should be sent to Creative Drama Journal's e-mail address (cdddergi@gmail. com). 
18. Author or authors who cite/s are responsible for the distortions that may be in the content of the published articles.

19. Studies carried out as dissertation in Creative Drama Instructor/Leadership courses are published with the name of advisor including the advisor name and second name.

20. The articles published in somewhere else (published seminar and conference proceedings, etc.) can be published in Creative Drama Journal with the approval of the Editorial Board.

\section{Citation Format and Style Guide for Creative Drama Journal}

Publication of Manual of American Psychological Association-APA is adopted by our journal for formatting and style.

\section{JOURNALS}

\section{One Author}

San, İ. (1998). The development of drama in education in Turkey, Research in Drama Education, 3, $1,96$.

\section{Two Authors}

Özdemir, P. ve Akkuş-Çıkla, O. (2005). Use of creative drama in science and mathematics by preservice elementary teachers. Hacettepe Üniversitesi Eğitim Fakültesi Dergisi, 27, 157-166.

\section{Books and Chapter in Books}

\section{One Author}

Üstündağ, T. (2004) Yaratıcı Drama Öğretmenimin Günlüğü (6. baskı). Ankara: PegemA Yayıncılık.

\section{Two Authors}

Kitson, N. ve Spiby, I. (1997). Drama 7-11: Developing Primary Teaching Skills (3rd ed.). New York: Routledge Publication.

\section{Editor instead of Author}

Hemingway, E. (1999). The killers. In J. Updike \& K. Kenison (Eds.), The best American short stories of the century (pp.78-80). Boston, MA: Houghton Mifflin.

Kilpatrick, J. (2004). (Ed.). A Research Companion to Principles and Standards for School Mathematics, Reston, VA: NCTM, Inc. Educational Research Information Center (ERIC)

\section{Thesis or Dissertation}

Duatepe, A. (2004). The effects of drama based instruction on seventh grade students' geometry achievement, Van Hiele geometric thinking levels, attitude toward mathematics and geometry. Unpublished PhD dissertation, Ankara: METU.

\section{Published Presentation Papers}

Adıgüzel, H. Ö. (2002). Eğitim bilimlerinde ve sanat eğitiminde yöntem, disiplin ve sanatsal boyutlarıyla yaratıcı drama. 11. Eğitim Bilimleri Kongresi, Yakın Doğu Üniversitesi, KKTC, 23-26 Ekim. 


\section{Online Journal}

Andersen, C. (2004, June). Learning in "As-If” worlds: Cognition in drama in education. Theory into Practice. 43, 4, Retrieved November 3, 2004, Academic Index.

\section{Citing in the text}

\section{One Author}

Linn's (1999) study...

As it is indicated (Way, 1973) in a new research,...

\section{Two or more Authors}

If the paper is published by two authors, then full names of both authors must be written through all the text. If the paper is published by three or more authors, then in the first citation full names of authors must be written, but then for other citations, only the first authors' first name must be written and other authors must be written as "others".

\section{Figures}

All the figures must have a title that include also a number. And this title must be under the figure.

\section{Tables}

The name and the number of table must be at the top of the table. Name of the table must begin after the number of table. And it must be aligned-left, written by initial capital letters and italic. The table must be constituted by only horizontal lines. You can find an example below.

\section{Tablo 1.}

\begin{tabular}{|c|c|c|c|c|c|}
\hline & 1. sinif & 2. $\sin 1 f$ & 3. sinif & 4. $\sin 1 f$ & 5. sinif \\
\hline & Fen ders & & & & \\
\hline Yaşayan canlılar & - & - & - & 5 & 1 \\
\hline \multirow[t]{2}{*}{ Elektrik } & - & - & 1 & 3 & - \\
\hline & Matema & & & & \\
\hline Sayılar & - & - & 1 & - & 1 \\
\hline Geometri & 1 & - & 3 & 1 & 1 \\
\hline Ölçme & - & 2 & 1 & - & - \\
\hline
\end{tabular}

